\title{
EFFECT OF EARLY HEAT CONDITIONING AND LIGHTING REGIME ON PHYSIOLOGICAL AND IMMUNE RESPONSES OF MUSCOVY DUCKS DURING SUMMER SEASON El-Badry, A. S. O. ${ }^{1}$; S. A. Abdel-Fattah ${ }^{2}$ and G. A. G. Moslim ${ }^{1}$ 1- Department of Rabbit Breeding Research, Animal Prod. Res. Inst., Agric. Res. Center, Ministry of Agric., Dokki, Giza, Egypt \\ 2- Poultry production Dept., Fac. of Agric., Ain Shams Univ., Cairo, Egypt
}

\section{ABSTRACT}

The objective of this study was to investigate the beneficial effects of early age thermal conditioning and lighting regime to reduc adverse effects of hot weather condition, especially on the oxidative stress and immune function of Muscovy ducks. Experimental design was a $2 \times 2$ (4 groups of 160 ducks) during summer season. Ducks were divided into two equal groups. The control group, maintained under normal ambient temperature, the second group were exposed to early age thermal conditioning (exposed to temperature of $39 \pm 1^{\circ} \mathrm{C}$ for $6 \mathrm{~h}$ at 5 th day of age and then subjected to normal ambient temperature. Each group of the previous groups were divided into subgroups at beginning 4 week of age. The first subgroup was subjected to normal day light ( $16 \mathrm{~h}$ light, $8 \mathrm{~h}$ dark) and the second subgroup was subjected to intermittent light regime of $4 \mathrm{~h}$ light $2 \mathrm{~h}$ dark (make 16h light, 8h dark). Blood samples were collected at 12 weeks of age for assay of some blood parameters.

The obtained results could be summarized as follows:

Body temperature was significantly decreased by both early-age thermal conditioning or intermittent light regime. Plasma lysozyme concentration of Muscovy ducks were insignificantly increased in early heat exposed group compared to the control group. However, it significantly increased in intermittent light regime group. Corticosterone level and Hetrophil/lymphocyte ratio decreased in both thermally-conditioned and intermittent light groups compared to control group. Plasma malondialdehyde was significantly decreased in early heat exposed group compared to the control group. However, it insignificantly decreased in intermittent light regime group compared to control group. Superoxide dismutase and catalase enzymes increased in both thermally-conditioned and intermittent light groups compared to control group. It is concluded that a combination of early age thermal conditioning and intermittent light regime reduces oxidative stress and improves immune responses and this combination can be considered as bio-stimulation methods for the birds to reduc the negative effects of high ambient temperature.

\section{INTRODUCTION}

High temperature beyond the thermoneutral zone causes environmental heat stress (HS). Chickens are more vulnerable to $\mathrm{HS}$ compared with other domestic animals because of feather covering and the lack of sweat glands and their higher body temperature (Sahin et al., 2009). Therefore, HS is a major stressor and causes a wide range of physiological alterations in chickens (Whitehead and Keller, 2003). As the heat load increases, the rise in body temperature results in tissue damage by HSinduced production of reactive oxygen species (ROS) (Khan et al., 2012).

Many practical approaches have been developed in attempts to facilitate the thermotolerance of birds, and to minimize the adverse effects of heat stress on productivity. Animals can be conditioned to an expected 
change in the environment. For instance, broiler chickens can be physiologically modulated by thermal conditioning in early life to improve heat stress tolerance in later life (De Basilio et al., 2001). The main idea in the thermal conditioning process is to manipulate immature mechanisms of temperature regulation in early life, enabling chickens to cope, within certain limits, with acute exposure to unexpected heat spells in later life (Yahav and McMurtry, 2001). In broiler chickens, thermal conditioning to heat at an early age resulted in reduced weight gain during the first week of life, followed by an accelerated growth (Yahav and McMurtry, 2001), improved thermotolerance, and reduced mortality when reexposed to heat in later life (De Basilio et al., 2001). Early thermal conditioning seems to be one of the most promising methods to improve the adaptability of broiler chickens to heat stress (Lin et al., 2006).

Melatonin (N-acetyl-5-methoxy tryptamine), the main secretory product of the pineal gland (Pang and Ralph, 1975), has been suggested to have immunomodulatory roles. It enhances the immune response and counteracts immunodeficiency states resulting from acute stress (Ben-Nathan et al., 1996). Much recent researches have been thus focused on comparisons between continuous Light (CL) and intermittent Light (IL). These researches suggest that intermittent lighting improves immune function (Moore and Siopes, 2000). Continuous Light appears to be more stressful than IL (Abbas et al., 2008). Under stress, excess free radicals are generated and can damage cell components such as lipids, protein, DNA, and carbohydrates (Payne and Southern, 2005). Melatonin is a potent antioxidant and scavenger of various free radicals especially hydroxyl and peroxyl radicals with enhancement of antioxidative enzyme activities in many tissues (Pieri et al. 1994).

Therefore, the objective of the current experiment was to assess the effect of early heat exposure and lighting regime and their combination on antioxidant status and immune function of Muscovy ducks.

\section{MATERIALS AND METHODS}

\section{Birds, Diet and Treatments:}

A total of 160 , one day-old Muscovy ducklings were used in this study. Ducks were divided into two equal groups. The control group, maintained under normal ambient temperature, the second group was exposed to early age thermal conditioning (exposed to temperature of $39 \pm 1^{\circ} \mathrm{C}$ for $6 \mathrm{~h}$ at 5 th day of age and then subjected to normal ambient temperature. The birds of all groups were maintained under continuous lighting program (23 $\mathrm{h}$ light, $1 \mathrm{~h}$ dark) for 4 weeks posthatching. All groups were then divided into two subgroups at the beginning of the $4^{\text {th }}$ week of age. The first subgroup was subjected to normal day light (16 h light, $8 \mathrm{~h}$ dark) and the second subgroup was subjected to intermittent light regime of $4 \mathrm{~h}$ light then $2 \mathrm{~h}$ dark (make $16 \mathrm{~h}$ light, $8 \mathrm{~h}$ dark).

Water and feed were given ad libitum throughout the rearing period. Crude protein and metabolizable energy levels in the starter and growing 
diets were $19.12 \%$ crude protein and $2865 \mathrm{kcal} \mathrm{ME} / \mathrm{Kg}$ diet and $15.04 \%$ crude protein and $2687 \mathrm{kcal} \mathrm{ME} / \mathrm{Kg}$ diet, respectively.

Measurements:

Seven birds from each group were selected randomly to determine the rectal temperature and respiration rate at 12 weeks of age. Rectal temperature was measured by inserting a thermometer in the cloacae at the depth of $3 \mathrm{~cm}$. Respiration rate was measured by counting the body wall movement per minute.

Also, blood samples were collected from the same ducks, from the wing vein into heparinized tubes. $\mathrm{PH}$ value was determined using digital electric $\mathrm{pH}$ meter immediately after collection of blood. Each blood sample was divided into two portions,: the first portion was immediately centrifuged at $3000 \mathrm{rpm}$ for 15 minutes and blood plasma was separated and stored at$20^{\circ} \mathrm{C}$ for further biochemical assay.

Plasma corticosterone and Triiodothyronine (T3) concentrations were determined by radioimmunoassay technique with commercial kits (Medical Technology, USA). Plasma lysozyme activity was measured by agarose gel lyses assay according to the method described by Schltz (1987).

The second portion of blood samples were taken to determine Hemoglobin concentration, Packed-cell volume (\%), red blood cells count ( $x$ $\left.10^{6} / \mathrm{mm}^{3}\right)$ and white blood cells $\left(\mathrm{x} 10^{3} \mathrm{~mm}^{3}\right)$. Hemoglobin concentration ( $\mathrm{gm} / 100 \mathrm{ml}$ blood) was determined by the hemoglobinometer (Pilaski, 1972).

The percentage of packed cell volume (PCV \%) value was determined according to Hunsaker (1969), Red blood cell's (RBC's) and white blood cell's (WBC's) were counted in fresh blood samples as described by Natt and Herrick, (1952) using haemocytometer and counted at $400 \mathrm{X}$ objective of a phase contrast microscope. Differential count of 100 leucocytes was done using blood smears stained with wright's stain and Heterophils / Lymphocytes ratio ( $\mathrm{H}$ : L ratio) was calculated.

Catalase (CAT) activity was determined according to Luck, (1963). Superoxide dismutase (SOD) was determined according to McCord and Fridovich, (1969). Malondialdehyde (MDA) was determined according to Buege and Aust, (1978).

\section{Statistical analysis:}

Data were analyzed by the least squares analysis of variance using the General Linear Models procedure of the statistical analysis model (SAS, 1999). The statistical model was as follows:

$$
Y_{i j k}=\mu+T_{i}+A_{j}+T A_{i j}+E_{i j k}
$$

Where: $Y_{\mathrm{ijk}}=$ Observation of the ij the ducks: $\mu=$ Overall mean, common element to all observations: $T_{i}=$ Effect of early heat exposure $\left(_{i}=1\right.$, 2); $A_{j}=$ Effect of light treatments $(j=1,2): T A_{i j}=$ Interaction effect between early heat exposure and light treatments and $\mathrm{E}_{\mathrm{ijk}}=$ Random error component assumed to be normally distributed. The significant differences among treatments were determined by Duncan's multiple range test (Duncan, 1955). 


\section{RESULTS AND DISCUSSION}

\section{Physiological Parameters:}

Body temperature (BT) and respiration rate (RR):

Ducks like all birds is a homothermia, it keeps its body temperature at a relatively constant level by thermoregultion, the body temperature of ducks depending on bird size, environmental temperature, age and sex (Strukie, 1986). There were significant differences due to heat treatments on body temperature or respiration rate.

As shown in Table 1 regardless of light programs the overall mean body temperature of Muscovy ducks were significantly decreased in early heat exposed group compared to the control group at ages studied.

Table (1): Effect of early heat exposure and light programs on body temperature and respiration rate of Muscovy ducks.

\begin{tabular}{|c|c|c|c|c|c|}
\hline \multirow[b]{2}{*}{ Item } & \multirow{2}{*}{$\begin{array}{c}\text { Light } \\
\text { programs }\end{array}$} & \multicolumn{2}{|c|}{ Heat treatments } & \multirow[b]{2}{*}{ SE } & \multirow{2}{*}{$\begin{array}{l}\text { Overall } \\
\text { mean }\end{array}$} \\
\hline & & H1 & $\mathrm{H} 2$ & & \\
\hline \multirow{2}{*}{ Body temperature ${ }^{\circ} \mathrm{C}$} & L1 & $41.45^{a}$ & $39.98^{b}$ & \multirow{2}{*}{ \pm 0.19} & $40.71 \pm 0.13$ \\
\hline & L2 & $41.38^{a}$ & $39.97^{b}$ & & $40.68 \pm 0.13$ \\
\hline \multicolumn{2}{|c|}{ Overall mean } & $41.42^{a}$ & $39.97^{b}$ & \pm 0.13 & \\
\hline \multirow{2}{*}{ Respiration rate /min } & L1 & $61.66^{\mathrm{a}}$ & $53.66^{c}$ & \multirow[b]{2}{*}{ \pm 0.75} & $57.66 \pm 0.52$ \\
\hline & L2 & $59.33^{b}$ & $54.83^{\mathrm{C}}$ & & $57.08 \pm 0.52$ \\
\hline \multicolumn{2}{|c|}{ Overall mean } & $60.50^{a}$ & $54.25^{b}$ & \pm 0.52 & \\
\hline
\end{tabular}

a, $b$, :Means in the same row bearing different superscripts are significantly different $\mathrm{H} 1=$ Normal ambient temperature, H2=High temperature

L1=Normal day light $\quad$ L2=Subjected to intermittent light regime of $4 \mathrm{~h}$ light $2 \mathrm{~h}$ dark

The numerically rise in body temperature in response to high environmental temperature in the present study was also reported previously by Osman, 1996. They considered that rectal temperature is a good indicator of both heat stress and acclimation. Early heat exposure caused significant decrease in body temperature. This could be due to the adaptive mechanisms which causing homeostatic reaction to prevent the rise in body temperature.

Results in Table 1 clearly show that respiration rate of Muscovy ducks during the whole experimental period reflected considerable changes. Statistical analysis of data elucidate that high temperatures caused highly significant effects on RR. However, the early heat exposed group had low RR values compared to the control group.

Although an increased RR (panting phenomenon) is desirable during higher ambient temperatures to dissipate the excessive heat, via evaporative cooling from the respiratory passages, our results failed to show this phenomena. This may be due to the beneficial effect of heat acclimation in reducing the metabolic heat production through their effects on thyroidal hormone secretion rates (discussed later) or via the effect of heat acclimation on adrenal gland function. The present results are in agreement with those of Tanizawa et al., (2014) who found the rectal temperature in experienced chicks was lower than that in control while there was no difference in respiration rate between the groups. On the other hand, Zhou et al. (1997) suggested that the heat exposure could make chicks cope with high 
environmental temperatures without panic because the lying time and the frequency of standing-lying in inexperienced chickens were significantly higher than in experienced chickens at a later age. Because posture to disturb heat loss (lying) and high-frequency posture change raises body temperature, they concluded that the experience might be useful for hyperthermic prevention.

Additionally, regardless of early heat exposure, the intermittent light group had slightly low BT and RR values compared to the continuous group (Table 1). These results are in accordance with those of Rozenboim et al. (1998) who concluded that pharmacological doses of melatonin induce hypothermia in hens by increasing non-evaporative skin heat losses and slightly increasing respiratory evaporation.

The increased in BT values in the control ducks compared to intermittent light group during high ambient temperatures was stressful and has induced hyperthermia in the ducks (Ndazo et al., 2012). The result demonstrated that the melatonin secretion has offered protection against the adverse effects of heat stress on the BT of the ducks. Moreover, melatonin plays an important role in circadian thermoregulatory adjustments of body temperature. Melatonin reduces heat production which led to lowering body temperature and regulating heat dissipation (Zeman et al., 2001). Also, melatonin may act by lowering the central set point temperature, thereby causing immediate stimulation of heat loss mechanisms.

\section{Plasma thyroidal hormones:}

The influence of heat acclimation and light programs treatments on thyroid hormone $\left(T_{3}\right)$ concentrations of ducks at 12 weeks of age are presented in Table 2. It is clear from the present results that, regardless of the light treatments, early heat exposure did influence the $T_{3}$ concentration of ducks. Moreover, early heat exposure resulted in an insignificantly increase in $\mathrm{T}_{3}$ level compared to control group. These results may infer an effect of early heat exposure on thyroid activity of the experimental ducks. Thyroid gland is involved in control of growth and develoment and exerts primary control of metabolic rate. Any treatments like heat stress that changes metabolic rate affect thyroid activity (May and McNaughton, 1980).

Exogenous thyroid hormone has a shorter survival time during heat stress (Bowen et al., 1984). Also, thyroid size and thyroid activity was reduced by high temperature and increased by low temperature in chickens (Huston et al., 1962). Tanizawa et al., (2014) suggest that reduced T3 may be a part of the mechanism associated with improved thermotolerance by early age heat conditioning. Also, Arjona et al. (1990) implied that thermogenesis might be reduced by early thermal conditioning due to reduced thyroid activity. Reduction in circulating triiodothyronine (T3) after early thermal conditioning has been reported (Yahav and Plavnik, 1999).

Additionally, regardless of early heat exposure, intermittent light group had significantly decreased plasma the values of $T_{3}$ compared to continuous light group (Table 2). This result is in a good agreement with that of Siam et al. (2004). Also, Olanrewaju et al. (2013) found that plasma T3 level of broilers reared under long continuous photoperiod (23L:1D) was 
significantly higher than those of broilers reared under intermittent (2L:2D). On the contrary, Klandorf et al. (1978) found that T3 and T4 of broilers had high levels during the photoperiod. Therefore, the high level of $T_{3}$ hormone in continuous photoperiod group probably relates to feed intake during the light period.

Corticosterone level:

As shown in Table 2 regardless of light programs the overall mean plasma corticosteron concentration of Muscovy ducks was significantly decreased in early heat exposed group compared to the control group at 12 wks of age.

Table (2): Effect of early heat exposure and light programs on plasma triiodothyronine $\left(T_{3}\right)$ and corticosterone levels of Moscovy ducks.

\begin{tabular}{|c|c|c|c|c|c|}
\hline \multirow[b]{2}{*}{ Item } & \multirow{2}{*}{\begin{tabular}{|c} 
Light \\
programs
\end{tabular}} & \multicolumn{2}{|c|}{ Heat treatments } & \multirow{2}{*}{ SE } & \multirow{2}{*}{$\begin{array}{c}\text { Overall } \\
\text { mean }\end{array}$} \\
\hline & & $\mathrm{H} 1$ & $\mathrm{H} 2$ & & \\
\hline \multirow{2}{*}{ T3 (ng/dl) } & L1 & $61.66^{b}$ & $73.33^{a}$ & \multirow[b]{2}{*}{ \pm 3.73} & $67.50^{\mathrm{a}} \pm 2.64$ \\
\hline & L2 & $62.83^{\mathrm{ab}}$ & $55.83^{\mathrm{b}}$ & & $59.33^{D} \pm 2.64$ \\
\hline \multicolumn{2}{|c|}{ Overall mean } & 62.25 & 64.58 & \pm 2.64 & \\
\hline \multirow{2}{*}{\begin{tabular}{|l} 
Corticosterone \\
$(\mathrm{ng} / \mathrm{ml})$
\end{tabular}} & L1 & $16.29^{a}$ & $10.97^{b}$ & \multirow{2}{*}{ \pm 0.52} & $13.63^{a} \pm 0.65$ \\
\hline & L2 & $11.31^{\mathrm{b}}$ & $8.21^{\mathrm{c}}$ & & $9.75^{b} \pm 0.65$ \\
\hline \multicolumn{2}{|c|}{ Overall mean } & $13.80^{a}$ & $9.59^{b}$ & \pm 0.65 & \\
\hline
\end{tabular}

a,b,c Means with different superscripts in the same row within item differ significantly $(\mathrm{P}<0.05)$.

$\mathrm{H} 1=$ Normal ambient temperature,

H2=High temperature

L1=Normal day light

L2=Subjected to intermittent light regime of $4 \mathrm{~h}$ light $2 \mathrm{~h}$ dark

The elevation of corticosterone noticed in the control group during high ambient temperature was compatible with previous researches (Geraret et al., 1996). They reported marked elevation in corticosterone level following heat stress exposure. Tanizawa et al. (2014) showed that attenuation of elevated levels of plasma corticosteron concentration would be a cause of suppressed febrile reaction in early heat exposed chicks under heat stress. Also, Star et al., (2009) found that corticosterone levels of hens (control group) were already higher than corticosterone levels of hens with "early life heat experience." during high ambient temperature.

The changes in triiodothyronine and corticosterone levels after early heat conditioning in this study may be part of the mechanism associated with improved thermotolerance by early age heat conditioning.

Additionally, regardless of early heat exposure, intermittent light group had significantly decreased plasma values of corticosterone compared to continuous light group (Table 2). In chickens under IL, corticosterone levels in the middle of the light period were significantly lower than chickens under CL under heat stress (Abbas et al.:2007). Melatonin treatment has been shown to attenuate adrenocortical secretory responses to acute and chronic stress (Konakchieva et al., 1997). 


\section{Blood pH and Blood haematological parameters:}

There were significant differences due to heat treatment in blood $\mathrm{pH}$, RBC's, PCV and Hb concentration. As shown in Table 3 regardless of light programs the overall mean blood $\mathrm{pH}$ of Muscovy ducks were significantly decreased in early heat exposed group compared to the control group.

Elevation of blood $\mathrm{pH}$ in control group was concomitant with increase in RR stated that carbon dioxide is an end product of oxidative metabolism in tissues and is converted to carbonic acid through the action of the enzyme carbonic anhydrase. The renal system regulates the loss of bicarbonate while carbon dioxide loss is mediated by the lungs. Under heat stress conditions birds regulate heat loss through the evaporation of water from their lungs. Odom (1982) showed that respiratory alkalosis developed within 60 min. after the onset of acute thermal change in heat stressed hens. This respiratory alkalosis causes disruption in blood flow patterns, body water distribution, and mineral and ionic balance (Smith and Teeter, 1993). Brees et al. (1989) observed that $\mathrm{pH}$ increased in chickens when exposed to increasing ambient temperature. However, Siegel et al. (1974) found no difference in blood pH for broiler reared under continuous $35^{\circ} \mathrm{C}$ vs. thermoneutral conditions. Reasons for these discrepancies are not clear but may include the degree of thermal stress, type of stress (Acute vs. chronic), blood collection site, sampling time relative to the respiratory state of birds or acclimatization of birds to continuous exposure to heat stress.

As shown in Table 3 regardless of light programs the overall mean RBC's, hemoglobin concentration and PCV of Muscovy ducks were significantly increased in early heat exposed group compared to the control group at ages studied.

Table (3): Effect of early heat exposure and light programs on some hematological parameters of Muscovy ducks.

\begin{tabular}{|c|c|c|c|c|c|}
\hline \multirow{2}{*}{ Item } & \multirow{2}{*}{$\begin{array}{c}\text { Light } \\
\text { programs }\end{array}$} & \multicolumn{2}{|c|}{ Heat treatments } & \multirow{2}{*}{ SE } & \multirow{2}{*}{$\begin{array}{c}\text { Overall } \\
\text { mean }\end{array}$} \\
\hline & & H1 & $\mathrm{H} 2$ & & \\
\hline \multirow{2}{*}{ Blood pH } & L1 & $7.63^{\mathrm{a}}$ & $7.44^{\mathrm{b}}$ & \multirow{2}{*}{ \pm 0.02} & $7.54^{a} \pm 0.02$ \\
\hline & L2 & $7.33^{c}$ & $7.24^{d}$ & & $7.23^{b} \pm 0.02$ \\
\hline \multicolumn{2}{|c|}{ Overall mean } & $7.48^{\mathrm{a}}$ & $7.34^{\mathrm{b}}$ & \pm 0.02 & \\
\hline \multirow{2}{*}{$\begin{array}{l}\text { RBC's } \\
\times 10^{6} / \mathrm{mm}^{3}\end{array}$} & L1 & $2.22^{b}$ & $2.97^{\mathrm{a}}$ & \multirow{2}{*}{ \pm 0.17} & $2.59^{b} \pm 0.12$ \\
\hline & L2 & $2.95^{\mathrm{a}}$ & $3.44^{\mathrm{a}}$ & & $3.19^{a} \pm 0.12$ \\
\hline \multicolumn{2}{|c|}{ Overall mean } & $2.58^{b}$ & $3.21^{\mathrm{a}}$ & \pm 0.12 & \\
\hline \multirow{2}{*}{$\begin{array}{l}\text { Hemoglobin } \\
\text { concentration (g/dl) }\end{array}$} & L1 & $11.54^{\mathrm{C}}$ & $17.93^{b}$ & \multirow{2}{*}{ \pm 0.78} & $14.74^{\mathrm{b}} \pm 0.55$ \\
\hline & L2 & $16.96^{b}$ & $20.36^{a}$ & & $18.66^{a} \pm 0.55$ \\
\hline \multicolumn{2}{|c|}{$\begin{array}{r}\text { Overall mean } \\
\end{array}$} & $14.25 \mathrm{~b}$ & $19.15^{\mathrm{a}}$ & \pm 0.55 & \\
\hline \multirow{2}{*}{ PCV \% } & L1 & $31.12^{b}$ & $31.36^{b}$ & \multirow{2}{*}{ \pm 0.32} & $31.24^{\mathrm{b}} \pm 0.23$ \\
\hline & L2 & $31.50^{\mathrm{b}}$ & $34.33^{\mathrm{a}}$ & & $32.91^{\mathrm{a}} \pm 0.23$ \\
\hline \multicolumn{2}{|c|}{ Overall mean } & $31.31^{b}$ & $32.84^{\mathrm{a}}$ & \pm 0.23 & \\
\hline
\end{tabular}

a, b, :Means in the same row bearing different superscripts are significantly different $\mathrm{H} 1=$ Normal ambient temperature, H2=High temperature

L1=Normal day light $\quad$ L2=Subjected to intermittent light regime of $\mathbf{4 h}$ light $\mathbf{2 h}$ dark 
The hematological data indicated decreased number of circulating RBCs and $\mathrm{Hb}$ concentration due to high ambient temperature. This may be due to the impact of chronic stress on iron $(\mathrm{Fe})$ in broilers and the hematopoietic process (Jamadar and Jalnapurkar, 1995). This result is in accordance with findings of Yahav et al. (1997), and these results are in accordance with Olayemi and Arowolo, (2009) in Nigerian ducks. During summer, high ambient temperature (HAT) increases body temperature, respiration and respiratory water loss and oxygen consumption of birds. The increased oxygen intake increases the partial pressure of oxygen in the blood of birds (Brackenbury et al., 1981) leading to decreased erythropoiesis and consequently, reducing the number of circulating erythrocyte (Donkoh, 1989). The PCV showed differential pattern, in control ducks there was an increased level under high ambient temperature. On the other hand, there was a decreased in PCV in thermally- conditioned ducks. Increased PCV in controls could be attributed to increased water loss due to panting and the birds were not able to adapt. In the case of thermally-conditioned birds, there was an adaptation response in the form of hemodilution to compensate water loss and an increase in the bird's ability to lose heat to the environment through water loss by evaporation without compromising plasma volume. Most of this evaporative water loss comes from the extra cellular component (Darre and Harrison, 1987).

Additionally, regardless of early heat exposure, intermittent light group had significantly decreased plasma the values of blood $\mathrm{pH}$ compared to continuous light group. Under a short photoperiod when respiration rate decreased (hypoventilation), the levels of pCO2 in blood increased and more $\mathrm{H}+$ ions accumulated, causing the $\mathrm{pH}$ of blood to decrease, thereby pushing the equilibrium reaction to the right and creating more hydrogen ions, thereby increasing hydrogen ion concentration, which lowered blood $\mathrm{pH}$ (Wideman et al., 2000).

Additionally, regardless of early heat exposure, intermittent light group had significantly increased plasma the values of red blood cells count, $\mathrm{Hb}$ and PCV compared to continuous light group (Table 3). These results agree with results obtained by Zhou et al., (1998) who found that red blood cells count and hematocrit values were greater during the dark than during the light period. Also, Sahin and Kucuk (2001) found that hematocrit values were higher in darkening groups compared with control group under heat stress and that is associated with hypoventilation and elevated pCO2 under extreme short photoperiod conditions. Hypoxemia coincides with diminished oxygen saturation of the blood (Julian and Mirsalimi, 1992) along with a concurrent increase in PCV and $\mathrm{Hb}$, which is a well-known physiological response to increase the oxygen-carrying capacity of blood (Luger et al., 2001).

The increase in RBCs count, PCV and $\mathrm{Hb}$ concentration obtained in the present study may be attributed either to its direct stimulatory effect on bone marrow, which was previously reported by Anwar et al. (1998) or indirectly through stimulation of some cytokins, which was found to have a powerful stimulatory effect on bone marrow cells proliferation (Lissoni et al., 1993). 


\section{Lysozyme concentration:}

Phagocytic cells are a source of lysozyme and when they are activated, lysozyme activity increases. Lysozyme plays an essential role in the regulation of cell differentiation and proliferation, in providing immunestructure tissue homeostasis. Lysozyme is an enzyme with antibacterial activity that can split peptidoglycanin bacterial cell walls particularly the gram species and it can cause lysis of the cells (Chipman and Sharon (1969).

Table (4): Effect of early heat exposure and light programs on immune responses of Muscovy ducks.

\begin{tabular}{|c|c|c|c|c|c|}
\hline \multirow{2}{*}{ Item } & \multirow{2}{*}{$\begin{array}{c}\text { Light } \\
\text { programs }\end{array}$} & \multicolumn{2}{|c|}{ Heat treatments } & \multirow{2}{*}{ SE } & \multirow{2}{*}{$\begin{array}{l}\text { Overall } \\
\text { mean }\end{array}$} \\
\hline & & H1 & $\mathrm{H} 2$ & & \\
\hline \multirow{2}{*}{$\begin{array}{l}\text { Lysozyme } \\
\text { concentration } \\
\text { (mg/l) }\end{array}$} & \multirow{2}{*}{$\begin{array}{l}\text { L1 } \\
\text { L2 }\end{array}$} & $2799^{\mathrm{b}}$ & $2598^{\mathrm{C}}$ & \multirow[b]{2}{*}{ \pm 0.30} & $26.98^{\mathrm{b}} \pm 0.21$ \\
\hline & & $27.51^{\mathrm{b}}$ & $31.06^{a}$ & & $29.28^{a} \pm 0.21$ \\
\hline \multicolumn{2}{|c|}{ Overall mean } & 27.75 & 28.52 & \pm 0.21 & \\
\hline \multirow{2}{*}{$\begin{array}{l}\text { WBC's } \\
\times 10^{3} / \mathrm{mm}^{3}\end{array}$} & L1 & $31.91^{\mathrm{b}}$ & $31.65^{b}$ & \multirow{2}{*}{ \pm 2.05} & $31.78^{b} \pm 1.45$ \\
\hline & L2 & $33.73^{\mathrm{ab}}$ & $38.36^{a}$ & & $36.06^{a} \pm 1.45$ \\
\hline \multicolumn{2}{|c|}{ Overall mean } & 32.83 & 35.01 & \pm 1.45 & \\
\hline \multirow{2}{*}{$\begin{array}{l}\text { Hetorphils }(\mathrm{H}) \\
\text { percentage }\end{array}$} & L1 & $32.37^{\mathrm{a}}$ & $22.77^{\mathrm{b}}$ & \multirow{2}{*}{ \pm 1.45} & $27.58^{a} \pm 1.03$ \\
\hline & L2 & $21.97^{b}$ & $21.38^{b}$ & & $21.68^{b} \pm 1.03$ \\
\hline \multicolumn{2}{|c|}{ Overall mean } & $27.17^{\mathrm{a}}$ & $22.08^{\mathrm{D}}$ & \pm 1.03 & \\
\hline \multirow{2}{*}{$\begin{array}{l}\text { Lemphocytes }(\mathrm{L}) \\
\text { percentage }\end{array}$} & L1 & $56.78^{C}$ & $69.37^{b}$ & \multirow{2}{*}{ \pm 2.89} & $63.08 b \pm 2.04$ \\
\hline & L2 & $63.97 b^{c}$ & $80.12^{\mathrm{a}}$ & & $72.04 a \pm 2.04$ \\
\hline \multicolumn{2}{|c|}{ Overall mean } & $60.37^{0}$ & $74.75^{a}$ & \pm 2.04 & \\
\hline \multirow{2}{*}{$\mathrm{H} / \mathrm{L} \%$} & L1 & $0.57^{\mathrm{a}}$ & $0.33^{b}$ & \multirow{2}{*}{ \pm 0.02} & $0.45^{a} \pm 0.02$ \\
\hline & L2 & $0.35^{b}$ & $0.26^{b}$ & & $0.31^{b} \pm 0.02$ \\
\hline \multicolumn{2}{|c|}{ Overall mean } & $0.46^{\mathrm{a}}$ & $0.30^{\mathrm{b}}$ & \pm 0.02 & \\
\hline
\end{tabular}

a, b, :Means in the same row bearing different superscripts are significantly different $\mathrm{H} 1=$ Normal ambient temperature- $\mathrm{H} 2=$ High temperature- L1=Normal day light$\mathrm{L} 2=$ Subjected to intermittent light regime of $\mathbf{4 h}$ light $2 \mathrm{~h}$ dark

As shown in Table 4 regardless of light programs the overall mean plasma lysozyme concentrations of Muscovy ducks were insignificantly increased in early heat exposed group compared to the control group at 12 wks of age. The immune system guards the body against foreign substances and protects from invasion by pathogenic organisms. It can be divided into the innate (nonspecific) immune system and the acquired (specific) immune system. In this study, early heat exposure linearly increased the content of plasma lysozyme, which is mainly secreted by phagocytes and is a nonspecific immune effector. The increased lysozyme concentration in birds subject to early heat can break down the polysaccharide walls of many types of bacteria and thus provides protection against infection.

The negative effect of high temperatures on the lysozyme concentration in control group could be related to a possible increase in corticosterone concentrations (Stoyanchev et al., 2010). According to Panarelli et al. [1994], glucocorticoid would induce repression of the lysozyme gene transcription, leading to the strong reduction of the circulating lysozyme concentrations. 
Additionally, regardless of early heat exposure, intermittent light group had significantly increased plasma concentration of lysozyme compared to continuous light group (Table 4). The pineal gland seems to control, via its hormone melatonin, the diurnal rhythm of nonspecific immunity in chickens and then induce serum lysozyme ( Skwarło-Sońta , 1991).

Immune responses:

Data in Table (4) regardless of light programs showed that heat treatments did not significantly affect total white blood cells count between groups. Also, as shown in Table 4 regardless of light programs the overall mean heterophils and $\mathrm{H} / \mathrm{L}$ ratio of Muscovy ducks were significantly decreased in early heat exposed group compared to the control group. While, overall mean lymphocytes count of Muscovy ducks were significantly increased in early heat exposed group compared to the control group.

Heterophils are phagocytic cells designed to defend the organism against infections by bacteria, viruses, or foreign particles, while lymphocytes play an important role in immunity, particularly for the production of antibodies. One of the physiological responses of exposure to stress is the release of glucocorticoids, causing dissolution of lymphocytes leading to lymphopenia and there is an increase in hetrophil release by the bone marrow, thus increasing their number in circulation (Swenson and Reece, 1996). Our findings for control birds are in accordance with those reported by Hester et al., (1996). The $\mathrm{H} / \mathrm{L}$ ratio has been accepted as the most sensitive and reliable index for determining the effect of various stressors in poultry and other livestock (Minka and Ayo, 2011). Our data on $\mathrm{H}$ : L ratio clearly showed that early age thermal conditioning was beneficial for the birds to withstand adverse effects of high ambient temperature at marketing age. Increase in $\mathrm{H} / \mathrm{L}$ ratio has been reported to reflect the effects of elevated corticosteroids in the circulation induced by stress (Kannan et al., 2002).

Additionally, regardless of early heat exposure, intermittent light group had significantly decreased heterophils and $H / L$ ratio compared to continuous light group (Table 4).

In this study intermittent light treatment induced a significant increase in total white blood cell count and lymphocyte percentage. These results are consistent with the previous reports which indicated that melatonin increased the total leukocytic count and lymphocyte percentage in broiler chicks (Abozahra et al., 1998). The precise mechanism responsible for this melatonin-induced increase in total leukocytic count and lymphocyte percentage is not clear. However, several mechanisms may be involved in this respect. The first possible mechanism may be the direct action of melatonin either on bone marrow (Kuci et al., 1987) or on lymphatic tissue (Maestroni and Conti, 1993) to accelerate leukocytogenesis (Conti et al., 1992). The second possible mechanism may be an indirect action through reduction of corticosterone hormone, which was reflected by the elevation of the leukocytic count (Anwar et al., 1998). The third possible mechanism may be through protection of bone marrow from damage by free radicals due to its antioxidant effect (Ahmed et al., 2005). The present investigation showed that intermittent light treatment significantly decreased the heterophil percentage. This result is matched with those reported by Abozahra et al. (1998). They 
found that melatonin significantly decreased the heterophil percentage in chicks. On the other hand, Sharma and Haldar (2006) attributed the mechanism by which melatonin exerts its immune-protection action to be partially due to its action in reducing the free radical load. In the same respect Cardinali et al. (2008) reported that melatonin stimulates the production of progenitor cells for granulocytes and macrophages. It also stimulates the production of natural killer cells and CD4+ cells and inhibits CD8+ cells. The production and release of various cytokines from natural killer cells and $T$ helper lymphocytes are enhanced by melatonin.

Lipid peroxidation and antioxidant indicators

As shown in Table 5 regardless of light programs the overall mean malondialdehyde (MDA) contents of Muscovy ducks were significantly decreased in early heat exposed group compared to the control group. While, overall mean SOD and CAT activities of Muscovy ducks were insignificantly increased in early heat exposed group compared to the control group (Table 5). In rabbits, total antioxidant capacity $(\mathrm{mmol} / \mathrm{l})$ and catalase (as antioxidative enzyme) activity in plasma of early heat group was higher than that of control group during hot condition (Abd EL-Kafy et al., 2008). The birds exposed to heat stress showed a significantly greater increase in oxidative damage in comparison with those experiencing heat stress at this time (David et al., 2012). Also, they showed that a thermal exposure period relatively early in life may induce responses against oxidative stress and, importantly, may prime the system of antioxidant to withstand oxidative stress induced by heat stress in adulthood. It is also possible that the activation of compensatory responses might have been traded off against the control of other functions later in life through, for example, a differential regulation of the expression of genes related to heat shock protein synthesis, antioxidant or DNA repair enzymes (Mattson and Calabrese, 2010).

Table (5): Effect of early heat exposure and light programs on oxidative status of Muscovy ducks.

\begin{tabular}{|c|c|c|c|c|c|}
\hline \multirow{2}{*}{ Item } & \multirow{2}{*}{\begin{tabular}{|c} 
Light \\
programs
\end{tabular}} & \multicolumn{2}{|c|}{ Heat treatments } & \multirow{2}{*}{ SE } & \multirow{2}{*}{$\begin{array}{l}\text { Overall } \\
\text { mean }\end{array}$} \\
\hline & & H1 & $\mathrm{H} 2$ & & \\
\hline \multirow[b]{2}{*}{ MDA $(\mathrm{nmol} / \mathrm{ml})$} & $\mathrm{L} 1$ & $2.56^{b}$ & $2.30^{b}$ & \multirow[b]{2}{*}{ \pm 0.12} & $2.43 \pm 0.08$ \\
\hline & L2 & $2.93^{\mathrm{a}}$ & $1.56^{\mathrm{C}}$ & & $2.24 \pm 0.08$ \\
\hline \multicolumn{2}{|c|}{ Overall mean } & $2.75^{\mathrm{a}}$ & $1.93^{b}$ & \pm 0.08 & \\
\hline \multirow{2}{*}{ CAT ( u/l ) } & L1 & $1.11^{\mathrm{C}}$ & $0.96^{\mathrm{C}}$ & \multirow{2}{*}{ \pm 0.06} & $1.04^{b} \pm 0.05$ \\
\hline & L2 & $1.52^{b}$ & $1.83^{\mathrm{a}}$ & & $1.67^{a} \pm 0.05$ \\
\hline \multicolumn{2}{|c|}{ Overall mean } & 1.31 & 1.40 & \pm 0.05 & \\
\hline \multirow{2}{*}{$\operatorname{SOD}(\mathrm{u} / \mathrm{l})$} & L1 & $0.39^{c}$ & $0.31^{\mathrm{d}}$ & \multirow{2}{*}{ \pm 0.01} & $0.36^{b} \pm 0.01$ \\
\hline & $\mathrm{L} 2$ & $0.56^{\mathrm{b}}$ & $0.69^{a}$ & & $0.63^{a} \pm 0.01$ \\
\hline \multicolumn{2}{|c|}{ Overall mean } & 0.48 & 0.51 & \pm 0.01 & \\
\hline
\end{tabular}

a, b, :Means in the same row bearing different superscripts are significantly different H1=Normal ambient temperature, H2=High temperature

L1=Normal day light $\quad$ L2=Subjected to intermittent light regime of $4 \mathrm{~h}$ light $\mathbf{2 h}$ dark

One of the key reasons for the increase of blood malondialdehyde (MDA) levels in the control groups is the increased temperature which can increase the lipid peroxidation of cells and subsequent detriments to the 
body. It has been reported that heat stress increases lipid peroxidation in poultry due to the increase in free radicals and also changes in blood $\mathrm{pH}$ (Siegel 1995).

Additionally, regardless of early heat exposure, intermittent light group had insignificantly decreased MDA compared to continuous light group (Table 5).

In this study intermittent light treatment induced a significant increase in superoxide dismutase and catalase enzymes compared to control group (Table 5).

In our study, decreased plasma MDA and increased SOD activity under the lighting regimes may help to restore the balance of oxidantantioxidant status and may enhance the ROS scavenging by elevating the concentration of SOD rather than GSH-Px. The beneficial effect of short periods and intermittent light on plasma MDA may also be attributable to melatonin, which is a powerful anti-oxidant that can protect against lipid peroxidation of cellular membranes (Hardeland, 2005). Abbas et al. (2008) suggests that $\mathrm{CL}$ is more stressful than an intermittent regime and stress generally destroys the balance of oxidant-antioxidant.

Physicochemical properties of the melatonin molecule give it high diffusion ability; thus, it can easily diffuse through subcellular compartments, such as cytosol, nucleus, cellular membranes, and mitochondria [Reiter et al., 1999]. In addition to its ability to scavenge peroxyl radicals, hydroxyl radicals, and other reactive oxygen species. Furthermore, melatonin stimulates the activity of several enzymes related to the antioxidative defense system [Tan et al., 2000]. In addition, melatonin augments production and regeneration of glutathione, one of the major intracellular antioxidant molecules. Melatonin also increases the activity of catalase [Karbownik and Reiter. 2001].

In conclusion, the current study suggests that early heat conditioning and intermittent light were beneficial to the antioxidant status and immune responses of Muscovy ducks. This intermittent light can not only maintain the normal balance of oxidant-antioxidant and enhance immune function, but also utilizes total lighting time effectively and reduces overall production costs by cutting illumination costs. Also, the changes in some physiological parameters after early heat conditioning may be part of the mechanism associated with improved thermotolerance by early age heat conditioning. These findings indicate the importance of considering management factors when making production decisions during hot weather condition.

\section{REFERENCES}

Abbas A. O., A.K. Alm El-Dein, A.A. Desoky and M. A.A. Galal (2008). The effects of photoperiod programs on broiler chicken performance and immune response. International J. of Poultry Science. 7: 665-671.

Abbas, Ahmed O. ; Ahmed E. Gehad, Gilbert L. Hendricks , H.B.A. Gharib and Magdi M. Mashaly (2007). The Effect of Lighting Program and Melatonin on the Alleviation of the Negative Impact of Heat Stress on the Immune Response in Broiler Chickens. International J. of Poultry Science 6 (9): 651-660. 
Abdel-Kafy E.M., Ali W.A.H., Hoda A.S., A.A.A. Azoz (2008). Effect of short heat exposure, balanced feed restriction and acetic acid supplement at post weaning on growth and thermoregulation in growing rabbits during hot season. 9th World Rabbit Congress - June 10-13- Verona - Italy

Abozahra, A. A., El-sayed, M., Elshazly, K. A. and M. F. Saad, (1998). The influence of melatonin on the immune response to IBD vaccination in broilers. J. Zagazig Vet., Med. 4th Vet. Med. Zag. Congress, $600-$ 608.

Ahmed, H.H., Essawy, G.S., Salem, H.A. and M.A. Abdel Daim, (2005). Melatonin has a strong antioxidant activity and improves liver and kidney functions in broiler chicks. Egypt. J. Basic and Appl. Physiol., 4(1), 77-92.

Anwar, M.M., Mahfouz, H. A. and A. S. Sayed, (1998). Potential protective effects of melatonin on bone marrow of rats exposed to cytotoxic drugs. Comp. Biochem. Physiol. A. Mol. Integr. Physiol., 199 (2), 49501.

Arjona A, Denbow DM and WD Jr. Weaver (1990). Neonatally-induced thermotolerance: physiological responses. Comp. Biochem. and Physiol. Part A; Physiology, 95: 393-399.

Ben-Nathan, D., G.J.M. Maestroni, S. Lustig, and A. Conti, (1996). Protective effects of melatonin in mice infected with encephalitis viruses. Arch. Virol. 140:223-230.

Bowen, S. J.; Washburn, K.W.; and T. M. Huston, (1984). Involvement of the thyroid gland in the response of young chickens to heat stress. Poultry Sci., 63: 66-69.

Brackenbury, J.H.; Avery, P. and M.Glesson, (1981). Respiration in exercising fowl. Oxygen consumption, respiratory rates and respired gases. J.Expt.Biol, 93:317-325

Brees, K. W.; Raup, T. J.; Bottje, W. G.; and T. W. Odom, (1989). Physiological responses of heat stress broilers fed nicarbazin. Poultry Sci. 68:428-434.

Buege, J. A. and S. D. Aust, (1978). Microsomal lipid peroxidation. Methods Enzymol 52: 302-310.

Cardinali, D.P., Esquifino, A.I., Sirinivasan, V. and S.R. Pandi-Perumal, (2008). Melatonin and immune system in aging. Neuroimmunomduolation, 15 (4-6), 272-278.

Chipman,D.M. and N. Sharon (1969). Mechanism of lysozyme action.Science.165:454-465.

Conti, A., Gattera, N. H. and G. Maestroni, (1992). Role of pineal melatonin and melatonin - induced immuno-opioids in murine leukemogenesis. Med. Oncol.Tumor Pharcother., 19 (2), 87-92.

Darre, M.J. and P.C. Harrison (1987). Heart rate, blood pressure, cardiac output and total peripheral resistance of Single Comb White Leghorn hens during an acute exposure to $35^{\circ} \mathrm{C}$ ambient temperature. Poult. Sci., 66: 541-547. 
David Costantini; Pat Monaghan and B. Neil (2012). Metcalfe early life experience primes resistance to oxidative stress. The Journal of Experimental Biology. 215, 2820-2826

De Basilio, V., M. Vilariño, S. Yahav, and M. Picard. (2001). Early age thermal conditioning and a dual feeding program for male broilers challenged by heat stress. Poult. Sci. 80:29-36.

Donkoh, A. (1989).Ambient temperature: A factor affecting performance and physiological response of broiler chickens. Intern.J.Biometeorol., 33:259-265.

Duncan, D. B. (1955). Multiple range and multiple F tests. Biometrics,11:142.

Geraret, P. A.; Padiha, J. C. F.; and S. Guillaumin (1996). Metabolic and endocrine changes iduced by chronic heat exposure in broiler chickens: Biological and endocrinological variables. Br. J. Nutrition, 75: 205.

Hardeland, R. (2005). Antioxidative protection by melatonin: multiplicity of mechanisms from radical detoxification to radical avoidance. Endocrin. , 27 : 119-30.

Hester, P.Y., W.M. Muir, J.V. Craig and J.L. Albright (1996). Group selection for adaptation to multiple hen cages: Hematology and Adrenal function. Poult. Sci., 75: 1295-1307.

Hunsaker, W. G. (1969). Species and sex differences in the percentage of plasma trapped in packed cell volume determinations in avian blood. Poultry Sci ., 48 : 907.

Huston, T. M.; Edwards, H. M.; and J. J. Williams (1962). The effects of high environmental temperature on thyroid secretion rate of the domestic fowl. Poultry Sci.,41:640-645.

Jamadar, S.J. and B.W.V. Jalnapurkar (1995). Effect of high ambient temperature on iron status of broilers. Indian Vet. J., 72: 577-579.

Julian, R. J., and S. M. Mirsalimi. (1992). Blood oxygen concentration of fastgrowing and slow-growing broiler chickens, and chickens with ascites from right ventricular failure. Avian Dis. 36:730-732.

Kannan G.; Terril T.H.; Kouokou B.; Gelaye S. and E.A. Amoah (2002). Simulated preslaughter holding and isolation effects on stress responses and live weight shrinkage in meat goats. J Anim Sci, 80:1771-1780.

Karbownik, A. L., and J. R. Reiter. (2001). Anticarcinogenic actions of melatonin which involve antioxidative processes: comparison with other antioxidants. Int. J. Biochem. Cell Biol. 33:735-753.

Khan RU, Naz S, Nikousefat Z, Selvaggi M, Laudadio V and V. Tufarelli (2012). Effect of ascorbic acid in heat-stressed poultry. World's Poultry Science Journal, 68: 477-490.

Klandorf, H.; Sharp, P. J. and I. J. H. Duncan, (1978). Variations in levels of plasma thyroxin and triiodothyronine in juvenile female chickens during 24- and 16-hr lighting cycles. Gen. Comp. Endocrin., 36:238248. 
Konakchieva, R., Y. Mitev, O.F. Almeida and V.K. Patchev (1997). Chronic melatonin treatment and the hypothalamo-pituitary-adrenal axis in the rat: attenuation of the secretory response to stress and effects on hypothalamic neuropeptide content and release. Biol. Cell., 89: 587596.

Kuci, S., Becker, J., Veit, G., Haldar, C., Handgretinger, R. and A. Attanasino, (1987). Circadian variations in the immunomodulatory role of the pineal gland. Neuroendocrinol. Lett., 9 (5), 287.

Lin, H., H. C. Jiao, J. Buyse, and E. Decuypere. (2006). Strategies for preventing heat stress in poultry. World's Poult. Sci. J. 62:71-85.

Lissoni, P., Barni, S., Fancini, G., Rovelli, F., Ardizzoia, A., Canti, A. and G.J. Maestroni, (1993). A study of mechanism involved in the immunostimulatory action on the pineal hormone in cancer patients. Oncol., 50 (6), 399-402.

Luck, H. (1963). Methods of Enzymatic Analysis. New York, NY, USA: Verlag Chemie Academic Press.

Luger, D., D. Shinder, V. Rzepakovsky, M. Rusal, and S. Yahav. (2001). Association between weight gain, blood parameters, and thyroid hormones and the development of ascites syndrome in broiler chickens. Poult. Sci. 80:965-971.

Maestroni, G. J. and A.Conti, (1993). Melatonin in relation to the immune system. In. Yu, H. S., Retier, R. J. (Eds). Melatonin biosynthesis, physiological effect and clinical applications, Chapter 11. New York: CRC Press, 289-309.

Mattson, M. P. and E. J. Calabrese, (2010). Hormesis: a Revolution in Biology, Toxicology and Medicine. New York and London: Springer.

May, J. D.; and J. L. McNaughton, (1980). Effects of dietary ascorbic acid, aspirin, lysine and thiouracil on thyroid activity. Poultry Sci., 59: 893 899.

McCord, J. M. and I.Fridovich (1969). Superoxide dismutase: an enzymatic function for erythrocuprein (hemocuprein). J Biol Chem 244: 60496055.

Minka N.S. and J.O. Ayo (2011). Modulating role of vitamins C and E against transport induce stress in pullets during the hot-dry conditions. ISRN Vet Sci Doi:10.5402/2011/497138.

Moore, C.B. and T.D. Siopes, (2000). Effect of lighting conditions and melatonin supplementation on the cellular and humoral immune responses in Japanese quail (Coturnix coturnix Japonica). Gen. Comp. Endocrin, 119: 95-104.

Natt, M. P. and C. A. Herrick (1952). A new blood diluent for counting the erythrocytes and leucocytes of chicken. Poult. Sci., 31, 735.

Ndazo Salka Minka1; Abubakar A Adeiza1; Fatima B. Hassan1 and Joseph Olusegun Ayo (2012). Effects of melatonin and transportation on rectal temperature, heterophil/lymphocyte ratio and behaviour of Japanese male quails (Coturnix japonica). New York Science Journal;5(6):52-59 
Odom, T. W. (1982). The effect of high environmental temperature induced acid-base disturbance on the utilization of calcium in the domestic hen. Ph.D. thesis, Univ. Illinois, Urbane, II.

Olayemi, F.O and R.O.A. Arowolo, (2009). Seasonal variation in the Haematological values of the Nigerian Duck. Int.J. Poult Sc., 8: 813815

Osman, A.A., (1996). Effect of heat stress and salts on blood picture of chicken during rearing period. M.Sc. Thesis, Fac. Agric. Cairo Univ.

Panarelli M.; Holloway C.D., Mulatero P., Fraser R. and C.J. Kenyon (1994). Inhibition of lysozyme synthesis by dexamethasone in human mononuclear leucocytes: an index of glucocorticoid sensitivity. J. Clin. Endocrinol. Metab., 78, 872-877.

Pang, S. F., and C. L. Ralph, (1975). Pineal and serum melatonin activities at mid-day and mid-night following pinealectomy or castration in male rats. J. Exp. Zool. 194:275-280.

Payne, R.L. and L.L. Southern, (2005). Changes in glutathione peroxidase and tissue selenium concentrations of broilers after consuming a diet adequate in selenium. Poultry Science ,84:1268-1276.

Pieri C., Marra M., Moroni F., Recchioni R. and F. Marcheselli (1994). Melatonin: a peroxyl radical scavenger more effective than vitamin $\mathrm{E}$. Life. Sci. 55, 271-276.

Pilaski, J. (1972). Vergleichenda untersuchungen wher den hemoglobinehalf des huhner and putenblutes in abhangigkeit. Vor alter undgeshlecht. Arch. Geflugelkunde, 37, 70.

Reiter, R. J., D. X. Tan, and J. Cabrera. (1999). The oxidant antioxidant network: Role of melatonin. Biol. Signals Recept. 8:56-63.

Rozenboim, I.; Miara, L. and D. Wolfenson, (1998). The thermoregulatory mechanism of melatonin induced hypothermia in chicken . Am.J. physiol. 274(Reg.Integrat. Comp. Physiol.43): R232R236.

Sahin K.; Sahin N.; Kucuk O.; A. Hayirili and AS.Prasad (2009). Role of dietary zinc in heat stressed poultry: A review. Poultry Science, 88: 2176-2183.

Sahin, K and O. Kucuk (2001). A simple way to reduce heat stress in laying hens as judged by egg laying, body weight gain and biochemical parameters. Acta Vet. Hung. 49(4): 421-430.

SAS Institute. (1999). SAS User's Guide. Version 8.02 ed. SAS Institute Inc., Cary, NC.

Schltz, L. A. (1987). Methods in Clinical Chemistry. The C V Mosby. Lost Louis, 742-740.

Sharma, S. and C. Haldar (2006). Melatonin prevents x-ray induced oxidative damages in peripheral blood and spleen of seasonally breeding rodent, during reproductively active phase. Int J Rad Biol, 82, 411419.

Siam, S. S., Ebrahim, K. M., Mansour, K. M. and R. H. Youssef (2004). Melatonin relation to serum hormonal and biochemical constituents and egg quality in laying hens at different ages. Egypt. Poult. Sci., 11:523-541. 
Siegel, H. S. (1995). Stress, strains and resistance. Br. Poultry Sci., 36: 3 22.

Siegel, H. S.; Drury, L.; and W. C. Patterson (1974). Blood parameters of broilers grown in plastic coops and on litter at two temperatures. Poultry Sci., 53: 1016 - 1024.

Skwarło-Sońta K. (1991). Pineal influence on the diurnal rhythm of nonspecific immunity indices in chickens. Journal of Pineal Research (Impact Factor: 7.81).; 10(4):190-195.

Smith, M. O.; and R. G. Teeter, (1993). Carbon dioxide, ammonium chloride, potassium chloride and performance of heat distressed broilers. J. Appl. Poultry Res. 2: $61-66$.

Star, L.; H. R. Juul-Madsen; E. Decuypere; M. G. B. Nieuwland; G. de Vries Reilingh; H. van den Brand; B. Kemp and H. K. Parmentier (2009). Effect of early life thermal conditioning and immune challenge on thermotolerance and humoral immune competence in adult laying hens. Poultry Science. 88 (11):2253-2261.

Stoyanchev, K.; L. Sotirov; N. Bozakova and T. Stoyanchev (2010). Natural humoral immunity in turkey breeders and broilers, healthy and with hereditary muscular dystrophy, reared under comfortable or stressful microclimatic conditions. Revue Méd. Vét., 2010, 161, 11, 515-520.

Sturkie, P. D. (1986). Avian Physiology. Springer-Verlag, Inc. New York. NY.

Swenson, M.J. and W.O. Reece (1996). Fisiologia DOS Animais Domesticos/Dukes. 11th Edn., Guanabara, Rio de Jaeiro, Brazil, ISBN: 8527703300, pp: 856.

Tan, D. X., L. C. Manchester, R. J. Reiter, S. F. Plummer, J. Limson, S. T. Weintraub, and W. Qi. (2000). Melatonin directly scavenges hydrogen peroxide: A potentially new metabolic pathway of melatonin biotransformation. Free Radic. Biol. Med. 29:1177-1185.

Tanizawa, h., jun-ichi shiraishi ; shin-ichi kawakami; masaoki tsudzuki and takashi bungo (2014). Effect of short-term thermal conditioning on physiological and behavioral responses to subsequent acute heat exposure in chicks. J. Poult. Sci., 51: 80-86.

Whitehead CC. and T. Keller (2003). An update on ascorbic acid in poultry. World's Poultry Science Journal, 59: 161-184.

Wideman, R. F., M. R. Fedde, C. D. Tackett, and G. E. Weigel. (2000). Cardio-pulmonary function in preascitic (hypoxemic) or normal broilers inhaling ambient air or 100\% oxygen. Poult. Sci. 79:415-425.

Yahav, S., A. Straschhnow, I. Plavnik and S. Hurwitz, (1997). Blood system response of chickens to changes in environmental temperature. Poult. Sci., 76: 627-633.

Yahav, S., and I. Plavnik. (1999). Effect of early-age thermal conditioning and food restriction on performance and thermotolerance of male broiler chickens. Br. Poult. Sci. 40:120- 126.

Yahav, S., and J. P. McMurtry. (2001). Thermotolerance acquisition in broiler chickens by temperature conditioning early in life-The effect of timing and ambient temperature. Poult. Sci. 80:1662- 1666. 
Zeman, M.V.; Buyse, J.; Herichova, J.I. and E. Decuypere, (2001). Melatonin decreases heat production in female broiler chicken. Acta Vet. Brno., 170: 15-18.

Zhou W, Fujita M, Ito T and S. Yamamoto (1997). Effects of early heat exposure on thermoregulatory responses and blood viscosity of broilers prior to marketing. British Poultry Science, 38: 301-306.

Zhou, W. T.; Fujita, M.; Yamamoto. S.; Iwasaki, K.; Ikawa, R. and H. Horikawa, (1998). Effects of glucose in drinking water on the changes in whole blood viscosity and plasma osmolality of broiler chickens during high temperature exposure. Poult. Sci., 77: 644-647.

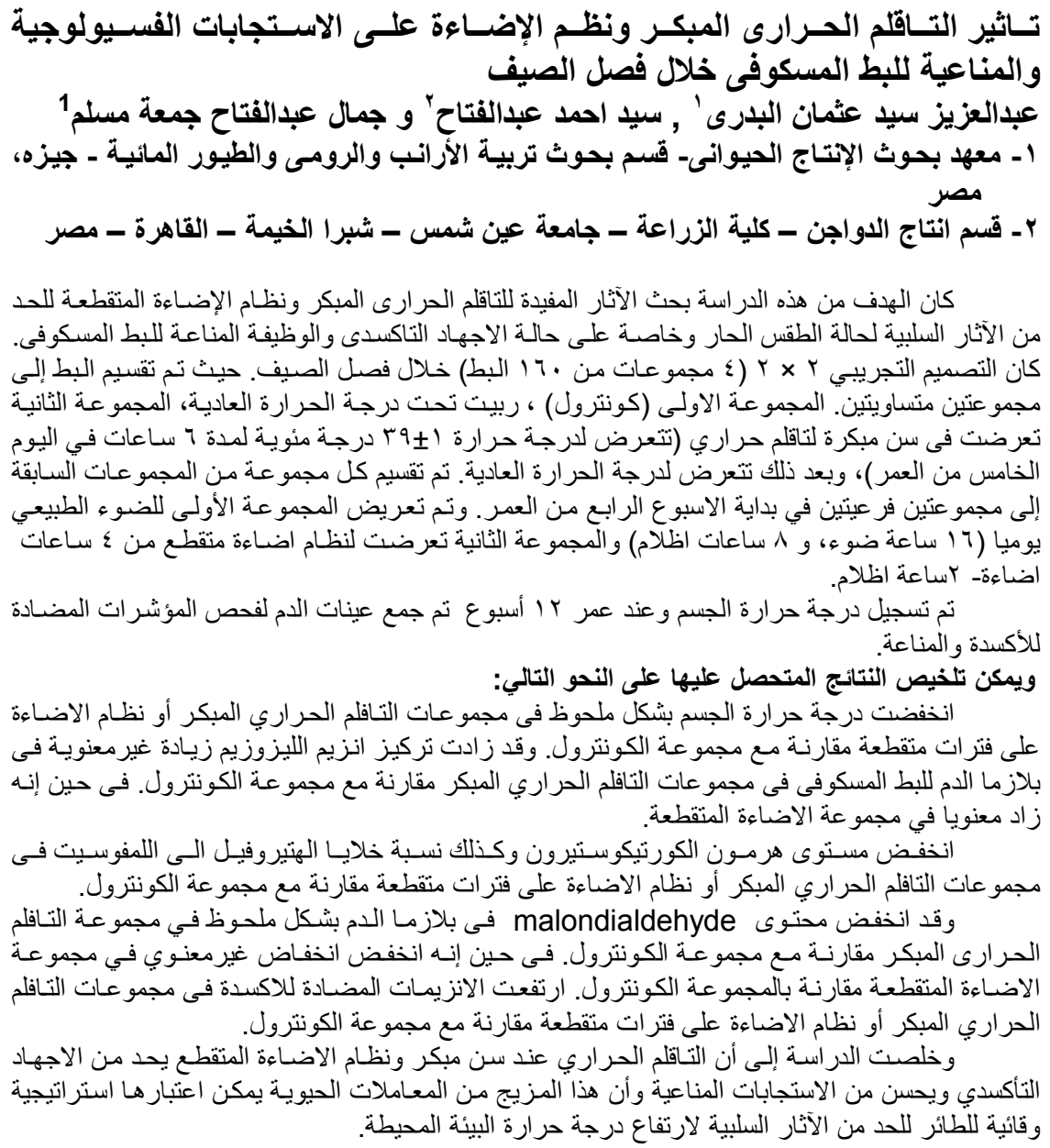

